\title{
LEVEL OF UNDERSTANDING AND REASONS CUSTOMERS CHOOSE SHARIA INSURANCE PRODUCT
}

\author{
Delvia Rusita Purnamasari', Azhar Alam²
}

1,2Departement of Islamic Economic Laws, Faculty of Islamic Studies, Surakarta Muhammadiyah University

E-mail:aa123@ums.ac.id(correspondence author)

\begin{abstract}
This study aims to determine the level of customer understanding of Islamic insurance products and reasons for customers to buy or become consumers of Islamic insurance. This research uses a quantitative approach with descriptive statistical analysis. This research took at PT. Solo Family Takaful of 100 respondents. The data collection method uses a questionnaire distributed to customers, and the data processing uses the Guttman Scale Cross-Sectional model (traditional) with the help of Microsoft Excel 2010 and SPSS 24. The results of this study indicate that the level of understanding and reasons for customers in choosing sharia insurance products are classified as high due to factors consumer interest and knowledge factors.
\end{abstract}

Keywords:Understanding of Sharia Insurance, Customers, Reasons of Choosing Sharia Insurance 


\section{Introduction}

Indonesia is one of the countries that has the most population number 4 in the world, with a total of $268,074,600$ inhabitants. Where many people need insurance in their lives for protection in the future and the present, besides that, the development of insurance in Indonesia is experiencing quite rapid development, which more customers are using insurance in their lives. Future risks can occur to the lives of people such as death, illness or being fired from work. Every risk that will be faced later must be addressed so as not to cause even more significant losses (Leliya and Kurniasari 2015).

According to the National Sharia Council, No.21 / DSN-MUI / X / 2001 Sharia Insurance is an effort to protect each other and help among several people make investments in the form of assets and or tabarru 'which provides a pattern of taking to face a risk or danger.

In Islamic history, the concept of insurance originated from the main idea of the Aqilah that the ancient Arab tribes had to be prepared to make financial contributions in the name of the killer to pay the heir to the victim. Readiness to pay financial contributions equals insurance premiums. Meanwhile, the compensation paid based on al-Aqilah may be the same as the amount of coverage in current insurance practice. Because, it is a form of financial protection for the testator against death that is not expected from the victim (Ismanto 2016, 119).

From the explanation above, it can be concluded that insurance has been used for a long time, both conventional insurance and sharia insurance. Insurance itself is a non-bank financial institution whose job is to overcome and minimize risks that might occur in some communities and also as a means to raise public funds so that it has a role in advancing public welfare.

The first Islamic insurance in Indonesia was established on February 24, 1994, namely PT Syarikat Takaful Indonesia, which was pioneered by ICMI (Indonesian Muslim Intellectual Association) (Sofhian and Suleman 2017). PT Syarikat Takaful Indonesia is a holding company that has two subsidiaries. First, family takaful is a form of takaful that provides financial protection in dealing with death and accident disasters for takaful participants. The family takaful products include takaful planning, takaful financing, takaful education, takaful hajj funds, takaful futures, takaful student accidents, takaful self-harm, and takaful khairat family. Second, general takaful, which is a form of takaful that provides financial protection in the face of disasters or accidents on the assets of takaful participants, such as houses, and buildings. Common takaful products include fire takaful, motorized vehicle takaful, sea transportation takaful, and engineering takaful(Syakir Sula 2016, 30).

Laws governing Islamic insurance include, among others, the Code of Commercial Law (KUHD), Law No. 2 of 1992 concerning Insurance Business, PP No. 81 of 2008 concerning the Third Amendment to PP No. 1992 concerning Conducting Insurance Business.

Based on data obtained from the Financial Services Authority (OJK), in 2018, sharia insurance assets will reach Rp. 41.96 trillion. The assets came from sharia general insurance Rp.5.62 trillion, sharia reinsurance Rp. 1.86 trillion and sharia life insurance Rp. 34.47 trillion. So that it can be estimated this year can penetrate Rp. 48.15 trillion.

The development of sharia insurance in Indonesia that is increasingly rapid must have a strategy carried out by the company so that success in the competition to attract the interest of the community. In this intense competition, insurance companies must have a goal to create and retain customers. For this purpose to be achieved, companies must work hard to create new strategic policies in selling their goods and services. With the increasing number of Islamic insurance companies, there are also more choices for customers to be able to choose products that are in line with their expectations(Sofhian and Suleman 2017). 
However, the problem of public understanding of sharia insurance cannot be separated from the problem of the understanding of each individual in looking at the legal aspects of the insurance itself (Ramadhan 2015). From the explanation that has been explained above, this study aims to explain the level of customer understanding and reasons for choosing Islamic insurance products at PT. Solo Family Takaful. The research is expected to be one of the references for sharia insurance product literacy.

\section{Litterature Review}

This study explored information from previous studies as a comparison. This paper obtained previously available information about theories relating to the title used to obtain the foundation of scientific theory.

Ramadan (2015) found the conclusion that the level of understanding of rural communities towards sharia insurance is still low while the supporting factors are education as the highest factor and the inhibiting factor is the low socialization factor and lack of information access. Kurniasari (2015) conclude what the factors that influence people's interest in sharia insurance, and there are psychological factors that encourage people to choose sharia insurance.

Jalaludin (2018) reveal the factors that influence the people of Aceh in the selection of Islamic insurance. His research results show that the independent variable is only the product, and religiosity significantly influences the community. In contrast, the price, location and promotion do not significantly influence the decision to choose Sharia Life Insurance in Banda Aceh. So people's perceptions about products and religiosity are the main, this can be seen the influence and relationship between perception with the selection of Sharia Life Insurance by 77.4 per cent.

Sofhian \& Suleman (2017) using multiple regression analysis tools on primary data and found that product quality factors have a positive and significant effect on customer decisions in choosing sharia insurance and religiosity have a positive and significant effect on customer decisions choosing sharia insurance.

Kania, Fauziah, \& Suwarsi, (2016)shows that the implementation of service quality, consumer knowledge and customer decisions at PT. Prudential Life Assurance Bandung Branch has been rated as useful ".(Kania, Fauziah, and Suwarsi 2016). Risa Nur Eka Sari (2018) states that the management of participant funds in AJB Bumiputera 1912 Syariah Division of Sidoarjo Branch in its management is divided into two accounts, namely participant's fund account and Tabarru 'fund account. In the management mechanism, it uses mudharabah contract as the morning of investment returns, with the proportion of profit-sharing $30 \%$ for insurance companies and $70 \%$ for participants(Sari 2018).

From the various literature review explanations above, it can be concluded that the specific differences and similarities between previous research and the research that the current author is first the existing research in the previous research mostly uses quantitative research using a Likert scale, whereas the author uses descriptive quantitative research methods using the Guttman scale. (2) From the previous research, the tool used to calculate the results of the research in SPSS. In contrast, the research that the writer will examine will discuss the understanding and reasons of customers in choosing sharia insurance products. (3) similarities with the literature review above are research on sharia insurance customers.

\section{The urgency of Customer Understanding in Choosing Products}

Understanding can be interpreted as a way to understand, assess or assess the characteristics, potential, and problems (disturbances) that exist in individuals or groups of individuals. Commonly used methods include observation, interview, rating scale, checklist, inventory, projective techniques, and several types of 
tests(Rahardjo and Gudnanto 2018, 37). Decision strategies explain the basic concepts of decision making, for example, decisions made by consumers in buying goods or services. So someone who is a customer of sharia insurance needs to know the contract, principles, and what benefits are in sharia insurance products. So, when customers decide to buy Islamic insurance products, according to what customers expect.

Factors that influence a customer's decision can be categorized into factors of interest and knowledge level factors (Wahyuningrum 2017). Interest is feelings of pleasure accompany a tendency to pay attention to people who act towards people whose activities or situations are the objects of interest. The consumer knowledge factor can be viewed from the higher level of knowledge possessed by consumers, the more knowledge about the product. This knowledge will later influence consumer decisions and trust in a product. Knowledge is information stored a person in the memory of his brain-some of these information functions for consumers to recognize the market.

\section{Basic Principles of Sharia Insurance}

Insurance is permitted if it does not deviate from the principles and rules of Islamic law. For that in muamalah must meet the necessary provisions taawun (cooperation), are mu'awadhoh, but tabarru ', donations (tabarru') are the same as grants (giving), intention to help in upholding the principles of ukhuwah, and carried out according to sharia principles(Nasution and Mugiyati 2010)

\section{Sharia Insurance Fund Management Mechanism}

Sharia operational insurance system, which happens is to be responsible, help and protect among the participants of sharia insurance. The participants of sharia insurance give the mandate to sharia insurance companies to manage premiums, develop in a halal way, provide compensation to those who experience the disaster according to the contents of the agreement. The company's profits derived from the distribution of profits of participant funds are developed using the mudharabah principle or profit-sharing system(Nasution and Mugiyati 2010).

The profits from the development of the fund are shared between participants and the Islamic insurance company by the terms (nisbah) previously agreed between the two parties. The participant fund management mechanism (premium) is divided into two systems of saving and nonsaving products (Syakir Sula 2016).

\section{Research Methods}

This type of research used by the author in writing this thesis uses field research, namely research, by collecting data directly from activities that have been carried out in the research workforce (Supardi 2005). The approach in this study is descriptive quantitative research on a particular population or sample. Sampling techniques are generally carried out randomly, data collection using research instruments, quantitative/statistical data analysis (Sugiyono 2009).

The population is a generalization area that consists of objects/subjects that have certain qualities and characteristics determined by researchers to be studied and then drawn conclusions. The population in this study is all customers in PT. Solo Family Takaful Insurance, amounting to approximately 1000 people. The sample with Slovin formula shows the number of respondents 90.9 rounded up to 100 respondents.

Data collection is done by questionnaire by giving a set of written questions to respondents to be answered. This questionnaire was given to customers of PT. Family Takaful Solo insurance to be filled out and returned to the researcher. Documentation is also one of the sources of data away that researchers do to find data that can be in the form of photos of activities, transcripts (Soehartanto 2004). Data collected in the form of brochures available at PT. Solo Family Takaful 
Insurance.

\section{Result and Discussion}

The level of understanding and reasons for customers in choosing Islamic insurance products in Takaful Family Solo is very high. However, some people do not understand the products they take. In this study, the authors used a questionnaire with the help of the Guttman scale to calculate respondents' answers. Understanding and reasons for customers in choosing Islamic insurance products is essential because it can determine the right choice according to their needs. To choose the product offered by the insurance, one must know what the benefits to be taken are. So, in this case, the customer's knowledge dramatically affects the product that will be taken.

This finding is in accordance with researchWahyuningrum (2017) entitled Factor Analysis on Customer Understanding About Sharia Insurance in AJB Bumiputera 1912 Syariah Division Sukoharjo Branch that several factors influence a customer's understanding in choosing sharia insurance products, including the following:

1. Interest Factor

Interest is a tendency to pay attention to people who act towards people whose activities or situations are objects of these interests, which are accompanied by feelings of pleasure.

2. Consumer Knowledge Factors

The higher the level of knowledge possessed by someone, the more knowledge a person has about an Islamic insurance product.

\section{Characteristics of Respondent Data}

The knowledge factor can also be seen from the characteristics of the respondents below:

\begin{tabular}{ll}
\multicolumn{2}{l}{$\begin{array}{l}\text { Table } 1 \text { Gender of } \\
\text { Respondents }\end{array}$} \\
\hline & Gender \\
\hline Male & 4 \\
Girl & 36 \\
\hline
\end{tabular}

As seen in Table 1, it can be seen that the number of male respondents is 64 people and female respondents are 36 people.

Table 2 Age List

\begin{tabular}{|c|c|}
\hline \multicolumn{2}{|c|}{ Age } \\
\hline $17-26$ years old & $\begin{array}{l}\text { Seven } \\
\text { people }\end{array}$ \\
\hline $27-36$ years old & 27 people \\
\hline $37-46$ years old & 25 people \\
\hline $47-56$ years old & 22 people \\
\hline $57-66$ years old & 19 people \\
\hline
\end{tabular}

Age dramatically influences one's comprehension and mindset, the more a person ages, the more the development of his comprehension and mindset will increase so that the knowledge he gets is getting better (Notoatmodjo 2007).

Can be seen from the table above, who chose sharia insurance from ages 1726 years as many as seven people, aged $27-36$ years as many as 27 people, aged $37-46$ years as many as 25 people, aged $47-56$ years as many as 22 people and 
age 57 - 66 years as many as 19 people. So it can be concluded that those who choose to become sharia insurance customers are mostly around 27-36 years old.

This can be clarified according to Sarwono, someone aged 25-29 years, including the most productive age group, where at that age someone's thinking is more critical, so it tends to find out everything (Notoatmodjo 2007).

At this age, most people already have a sufficient level of income, so that in purchasing Islamic insurance products, they do not feel too burdened by the payment of the products they buy. Alternatively, in another sense, the person can coordinate the income they earn.

This is following the research of Said and Amiruddin (2017) that at the age of 27-36 years most people are married, and at that time people who are married have a higher level of financial literacy than unmarried (Said and Amiruddin 2017)(Said and Amiruddin 2017)(Said and Amiruddin 2017)(Said and Amiruddin 2017).

Table 3 Job Listings

\begin{tabular}{ll}
\hline Profession & \\
\hline Government employees & 38 people \\
Private employees & 21 people \\
entrepreneur & 21 people \\
Others & 20 people \\
\hline
\end{tabular}

Work can

indirectly affect one's education level because work has a very close relationship with social and cultural interaction factors(Notoatmodjo 2007). This positively can affect the level of customer knowledge.

Then the table above explains the work taken by customers of PT. Takaful Kelvarga Solo. It can be seen from the table above that the most livelihoods are Civil Servants with a total of 38 people.

Table 4 Register Where to Know Insurance

\begin{tabular}{lc}
\hline \multicolumn{2}{c}{ How Do You Know Insurance? } \\
\hline Insurance agent & 35 \\
Friends / Relations & 35 \\
Pamphlet & 11 \\
Family & 16 \\
Others & 3 \\
\hline
\end{tabular}

Furthermore, the table above explains how one knows about Islamic insurance circulating in the community. In this case, there needs to be a promotion carried out both by the Islamic insurance agent itself and others. Promotion is vital to inform a product to consumers. Promotion in an era like now is not enough word of mouth, print media, and also other online media.

This is under research conducted by Jalaludin in Factors Affecting the Banda Aceh Community in the Selection of Sharia Life Insurance, that promotion is one of the media used by producers to attract consumers to buy/choose goods or services(Jalaludin 2018). The more promotions carried out by insurance companies, and the more consumers will know about the products of the sharia insurance company so that it can improve consumers' decisions in buying/choosing sharia insurance products (Jalaludin 2018).

This is also consistent with research conducted by Strong Ismanto in Factors That Influence the Decision to Purchase Sharia Insurance Products in Pekalongan, that marketing factors are more consideration of customers in purchasing Islamic 
insurance, compared to other factors(Ismanto 2016).

From the table above it can be seen where a customer knows sharia insurance. Most of them know the existence of Islamic insurance is from the Islamic insurance agent itself and friends/relatives.

Table 5 Register as a Customer

\begin{tabular}{ll}
\hline \multicolumn{2}{c}{ Long Time Being a Customer } \\
\hline Less than one year & 12 people \\
1-3 years & 57 people \\
$4-5$ years & 28 people \\
More than five years & Two persons \\
\hline
\end{tabular}

Then

the table above explains how long has someone been an Islamic insurance customer at PT. Solo Family Takaful. From the table above it can be seen that those who take Islamic insurance for less than one year are 12 people, 1-3 years are 57 people, 4-5 years are 28 people and those who are customers for more than five years are two people. So it can be concluded that most are customers of Islamic insurance for $1-3$ years, namely around 57 people.

Table 6 List of Sharia Insurance Products

\begin{tabular}{ll}
\hline \multicolumn{1}{c}{ Insurance Products } & \\
\hline Takaful Education Fund & 2 \\
Takaful Salam & 2 \\
Takafulink Greetings Scholar & 5 \\
Takafulink Greetings Pilgrimage Baitullah & 5 \\
Takafulink Salam Wakaf & 4 \\
Takafulink Greetings Comunity & 3 \\
Takaful Al-Khairat Individual & 6 \\
Individual Personal Accident Takaful & 4 \\
Takaful Al-Khairat Collection & 3 \\
Fulmedicare Gold & 9 \\
Takaful Pilgrimage & 5 \\
Takaful Financing & 5 \\
Hajj Insurance & 5 \\
Falah Saving & 2 \\
\hline
\end{tabular}

table explains

the various types of products that exist in the insurance company PT. Solo Family Takaful. The products offered include Takaful Educational Funds, Takaful Salam, Takafulink Salam Scholar, Takafulink Salam Pilgrimage Baitullah, Takafulink Salam Wakaf, Takafulink Salam Comunity, Takaful Al Khairat Individual, Takaful Individual Personal Accident, Takaful Al Khairat Collection, Fulafedict Salam Wakaf, Takafulink Salam Comunity, Takaful Al Khairat Individual, Takaful Individual Personal Accident, Takaful Al Khairat Collection, Fulafedic Salam Wagf, Takaful Zi Salam Salam, Takaful Financing, Haij Insurance, and Falah Saving. The product has an essential role in purchasing decisions so that someone who buys the product does not feel disadvantaged.

Jalaludin (2018) explained that the focal point of marketing activities is the product because the product is the result of a company that can be offered to the public for consumption and is a tool of a company to achieve its goals. (Jalaludin 2018). So a product must have advantages over other products both in terms of quality, size, packaging, shape, warranty, service, and taste in order to attract consumers to try, buy and choose the product to buy.

It can be seen from the table above that the most popular sharia insurance 
product is the Takaful Education Fund because every parent would want their children to be able to get a higher and better education later.

This is in line with Sutomo's research in the journal perception, and Awareness of Islamic Education Fund Insurance for Parents of Madrasah Aliyah Students, that parents' awareness of education fund insurance should indeed be high, due to the transfer of the risk of education funding to Islamic insurance companies according to the Muslim consumption model that stated by Khan inSutomo (2015) That Muslim consumption choices are divided into four, among others: the first choice based on the world and ukhrawi, the second choice based on current and future conditions, the primary choice of the third dharuriyat, hajiyat, and tahsiniyat, the fourth choice is a substitute.

\section{Understanding and Reasons for Customers Choosing Sharia Insurance Products}

In this study, in order to make it easier for authors to calculate the results of answers from questionnaires that have been filled out by respondents, the authors use a cross-sectional Guttman scale model (traditional). From the results of the questionnaire above, it will then be transferred to the frequency distribution table:

\begin{tabular}{ccc} 
Table 7 List of Answers & & \\
\hline Question & (\%) Answer Yes & (\%) Answer No \\
\hline Q1 & 100 & 0 \\
P2 & 89 & 11 \\
Q3 & 89 & 11 \\
Q4 & 100 & 0 \\
Q5 & 93 & 7 \\
TOTAL & 471 & 29 \\
AVERAGE & $\mathbf{9 4 . 2}$ & $\mathbf{5 . 8}$ \\
\hline
\end{tabular}

The percentage of "Yes" answers from the questionnaire above, it will be calculated first as follows:

Value of the answer "Yes": 1

Answer value "No" : :0

Then it will be converted into a percentage which is as follows:

Average answer "Yes": $\frac{94,2}{100} \times 100 \%=94.2 \%$

Based on the Guttman Scale analysis, the point of conformity that is above $50 \%$ is said to be "Approaching the Accord". So it can be concluded from the calculation above, the understanding and reasons of customers in choosing sharia insurance products are appropriate, with a percentage of $94.2 \%$.

In addition to several factors that have been described in the characteristics section of the respondent, the level of confidence also affects a person in taking an Islamic insurance product. Because when customers choose/buy the products they want, then they also believe that the product can provide excellent benefits for themselves and others.

It is also per the research of Sofhian and Sri Nur Ain Suleman that the dimension of belief/ideology is the degree to which a person believes in dogmatic matters in his religion, such as belief in God, angels, heaven and hell. So the dimension of belief is more doctrinaire that must be obeyed by someone(Sofhian and Suleman 2017). In research conducted by Ismanto (2016) that religiosity also has a positive effect on purchasing decisions for sharia insurance products. Religiosity is important in supporting the strength of culture and has a significant influence on buyer behavio(Ismanto 2016)(Ismanto 2016)(Ismanto 2016) (Ismanto 2016)ur. The implication is that marketing needs to consider consumer religiosity as segmentation variables for marketing products and services (Ismanto 2016).

Then another factor that drives customers of PT. Takaful Keluarga Solo to become members is the reputation of the insurance company itself. According to 
the surrounding community, the sharia insurance company provides appropriate services, and its employees are also amiable.

This is also consistent with Maya Kurniasari's research, that if a company has an excellent reputation out there, there will be many people who want to become one of the customers in the insurance company. (Kurniasari 2015).

\section{Conclusion and Recommendation}

The level of customer understanding of PT. Takaful Solo Family in taking Islamic insurance products is high. This can be known through several factors, namely the interest factor and consumer knowledge factor. The exciting factor itself is the situation that is the object of that interest which is accompanied by pleasure. While the consumer knowledge factor is that if a person has a high level of knowledge, the more knowledge a person has about a sharia insurance product that he chooses. In the consumer knowledge factor, it can be seen from the characteristics of the respondent's data that has been filled out by the respondent itself, and the highest level of knowledge is in the characteristics of the respondent's data section of sharia insurance products, the product with the most interest is takaful education funds,

The reason customers buy or become consumers of Islamic insurance is that they need the product they choose, the products available at PT. The Solo Family Takaful also has no elements of gharar, maysir, and usury 'so that with the hope that the product they choose can bring blessings and can also improve the future because it is in accordance with predetermined Islamic law.

Based on the findings made by researchers, the highest level of knowledge of Islamic insurance products is in the Takaful Education Fund products. Takaful Solo Family needs to be offered as the newest products for the customer. This research is expected to be used as reference material, and there is also a need for further research on the level of understanding and reasons for customers choosing sharia insurance products. Further research can also be conducted at several sharia insurance companies as well as on the level of understanding and reasons for customers choosing sharia insurance products.

\section{References}

[1] lsmanto, Kuat. 2016. "Faktor - Faktor Yang Mempengaruhi Keputusan Pembelian Produk Asuransi Syariah Di Pekalongan." Jurnal Hukum Islam (Journal of Islamic LaW) - JHI 14 (1).

[2] Jalaludin. 2018. "Faktor-Faktor Yang Mempengaruhi Masyarakat Banda Aceh Dalam Pemilihan Asuransi Jiwa Syariah." Jurnal Perspektif Ekonomi Darussalam 4 nomor 1: 118-38.

[3]Kania, Nia, N Eva Fauziah, and Sri Suwarsi. 2016. "Pengaruh Kualitas Pelayanan Dan Pengetahuan Konsumen Terhadap Keputusan Nasabah Dalam Memilih Produk Asuransi Syariah Di PT. Prudential Life Assurance Cabang Bandung." In Prosiding Kevangan Dan Perbankan Syariah, 2:769-76.

[4]Kurniasari, Maya. 2015. "Minat Nasabah Berasuransi Syariah (Studi Kasus Di Perusahaan Asuransi Prudential Super Agency Cirebon I)." Institut Agama Islam Negeri Syekh Nurjati Cirebon. https://doi.org/10.1 145/3132847.3132886.

[5]Leliya, and Maya Kurniasari. 2015. "Minat Masyarakat Berasuransi Syariah Di Asuransi Prudential." Institut Agama Islam Negeri Syekh Nurjati Cirebon.

[6]Nasution, Ajarotni, and Mugiyati. 2010. Analisis Dan Evaluasi Hukum Tentang Perasuransian (Asuransi Syariah) Undang-Undang Nomor 2 Tahun 1992. Jakarta Timur: Badan Pembinaan Hukum Nasional Kementerian Hukum dan Hak Asasi Manusi RI.

[7]Notoatmodjo, Soekidjo. 2007. Promosi Kesehatan Dan IImu Perilaku. I. Jakarta: PT Rineka Cipta.

[8]Rahardjo, Susilo, and Gudnanto. 2018. Pemahaman Individu. Jakarta: Prenada 
Media.

[9]Ramadhan, Ikromullah. 2015. "Pemahaman Masyarakat Pedesaan Terhadap Asuransi Syariah." Universitas Islam Negeri Syarif Hidayatullah Jakarta.

[10]Said, Salmah, and Andi Muhammad Ali Amiruddin. 2017. "Literasi Keuangan Syariah Di Perguruan Tinggi Keagamaan Islam (Studi Kasus UIN Alauddin Makasar)." Al- Ulum 17 nomor 1 (1): 76-85. https://doi.org/10.9744/jmk.17.1.76.

[11]Sari, Risa Nur Eka. 2018. "Analisis Pengelolaan Dana Tabarru' Dalam Produk Asuransi Mitra Iqra' Di AJB Bumiputera 1912 Divisi Syariah Cabang Sidoarjo." Universitas Islam Negeri Sunan Ampel.

[12]Soehartanto, Irawan. 2004. Metode Penelitian Sosial: Suatu Teknik Penelitian Bidang Kesejahteraan Sosial Dan IImu Sosial Lainnya. Bandung: Remaja Rosdakarya.

[13]Sofhian, and Sri Nur Ain Suleman. 2017. "Pengaruh Kualitas Produk Dan Religiusitas Terhadap Keputusan Nasabah Dalam Memilih Asuransi Syariah Di PT. Prudential Life Anssurance Cabang Kota Gorontalo." Li Falah Jurnal Studi Ekonomi Dan Bisnis Islam 2 nomor 1: 155-82.

[14]Sugiyono. 2009. Metode Penelitian Bisnis. Bandung: Alfabet.

[15]Supardi. 2005. Metodologi Penelitian Ekonomi Dan Bisnis. Yogyakarta: Ull Press.

[16]Sutomo. 2015. "Persepsi Dan Kesadaran Berasuransi Dna Pendidikan Syariah Orang Tuan Peserta Didik Madrasah Aliyah." Jurnal Saintifika Islamica 2 Nomor 1: $1-14$.

[17]Syakir Sula, Muhammad. 2016. Asuransi Syariah (Life and General) Konsep Dan Sistem Operasional. Jakarta: Gema Insani.

[18]Wahyuningrum, Suci. 2017. "Analisis Faktor Pada Pemahaman Nasabah Tentang Asuransi Syariah Di AJB Bumiputera 1912 Divisi Syariah Cabang Sidoarjo." Universitas Islam Negeri Sunan Ampel. 